\title{
Hubungan Tingkat Pengetahuan Terhadap Perilaku Penggunaaan Obat Antibotik Amoksisilin Pada Siswa Sma Negeri Di Kabupaten Pekalongan
}

\author{
Arizqa Fitria Dinata ${ }^{1}$, Wulan Agustin Ningrum ${ }^{2 *}$, Ainun Muthoharoh ${ }^{3}$, \\ Yulian Wahyu Permadi ${ }^{4}$, \\ 1,2,3,4Program Studi Sarjana Farmasi, Universitas Muhammadiyah Pekajangan Pekalongan, \\ Indonesia \\ *email:wulan1414@yahoo.co.id
}

\begin{abstract}
Self-medication by taking antibiotics is one of the inappropriate use of antibiotics that can cause bacterial resistance to drugs. This inaccuracy is the result of a lack of public knowledge about the use of antibiotics. The use of amoxicillin occurred in an 18-year-old child who had a toothache, then checked himself at the puskesmas in Pekalongan district and received the antibiotic amoxicillin, then there was a case when a teenager's hand was hit by a sharp object and was taken to the puskesmas in Pekalongan Regency and then received amoxicillin antibiotic. The purpose of this study was to determine the level of knowledge and behavior of public high school students in Pekalongan Regency and to find out whether there was a relationship between knowledge and behavior by using a research tool in the form of a questionnaire. This research is a research in the form of a survey with sampling using cluster random sampling method. The samples used in this study were high school students in class XI majoring in science and social studies at state high school students in Pekalongan Regency. The results show that the level of knowledge of the SMA Negeri students in Pekalongan Regency is moderate, which is $60.7 \%$, while the results in the behavioral category of the respondents are $66.0 \%$. The results of the correlation test analysis in this study that there is a significant relationship between the knowledge variable and the behavioral variable.
\end{abstract}

Keywords: Antibiotics; Knowledge; Behavior

\begin{abstract}
Abstrak
Pengobatan sendiri dengan mengkonsumsi obat antibiotik merupakan salah satu ketidaktepatan penggunaan antibiotik yang dapat menyebabkan resistensi bakteri terhadap obat. Ketidaktepatan ini merupakan akibat dari kurangnya pengetahuan masyarakat terhadap penggunaan obat antibiotik. Penggunaan amoksisilin terjadi pada seorang anak berusia 18 tahun yang mengalami sakit gigi, kemudian memeriksakan diri di puskesmas yang berada di kabupaten pekalongan dan mendapatkan obat antibiotik amoksisilin, kemudian adapula kasus ketika tangan seseorang remaja terkena oleh benda tajam dan dibawa ke puskesmas di Kabupaten Pekalongan lalu mendapat obat atibiotik amoksisilin. Tujuan penelitian ini untuk mengetahui tingkat pengetahuan dan perilaku pada siswa SMA Negeri di Kabupaten Pekalongan dan mengetahui apakah terdapat hubungan antara pengetahuan dengan perilaku dengan menggunakan alat penelitian berupa kuesioner. Penelitian ini merupakan penelitian dalam bentuk survei dengan pengambilan sampel menggunakan metode cluster random sampling. Sampel yang digunakan pada penelitian ini berupa anak SMA kelas XI jurusan IPA dan IPS pada siswa SMA Negeri di Kabupaten Pekalongan. Hasil menunjukan bahwa tingkat pengetahuan pada siswa SMA Negeri di Kabupaten Pekalongan ialah sedang yaitu sebanyak $60,7 \%$, sedangkan hasil pada kategori perilaku responden ialah $66,0 \%$. Hasil analisa uji korelasi pada penelitian ini ialah terdapat hubungan bermakna antara variabel pengetahuan dengan variabel perilaku.
\end{abstract}

Kata Kunci: Antibiotik; Pengetahuan; Perilaku 


\section{Prosiding Seminar Nasional Kesehatan 2021 Lembaga Penelitian dan Pengabdian Masyarakat Universitas Muhammadiyah Pekajangan Pekalongan}

\section{Pendahuluan}

Antibiotika dan resistensi, merupakan dua hal yang yang tak terpisahkan. Seiring dengan berkembangnya zaman, pemakaian antibiotika dalam bidang kesehatan semakin luas, serta manfaat yang diperoleh pun semakin besar. Namun semakin tinggi pula angka kejadian resistensi terhadap antibiotika di masyarakat. Resistensi antibiotika menyebabkan infeksi yang sering menjadi sulit untuk diobati dan dapat membahayakan nyawa serta pasien yang terinfeksi, hal ini memerlukan terapi yang lebih lama dan mahal.Resistensi merupakan kemampuan suatu bakteri untuk menetralisir danmelemahkan daya kerja obat antibiotik yang dikarenakan oleh kebalnya suatu bakteri dalam tubuh akibat dari ketidaktepatan penggunaannya.Amoksisilin merupakan obat generik dan termasuk golongan obat penisilin. Amoksisilin merupakan antibiotik golongan $\beta$-lactam yang berspektrum luas dan sering digunakan untuk mengobati berbagai penyakit infeksi yang disebabkan oleh bakteri Gram positif dan bakteri Gram negatif, seperti infeksi telinga, pneunomia, faringitis, streptokokus, infeksi kulit, infeksi saluran kemih, infeksi Salmonella, infeksi Chlamidya dan penyakit Lyme [7].

Pada tahun 2013 terdapat penelitian yang dilakukan oleh Morthy di Puskesmas Padang Bulan Medan. Penelitian tersebut menyebutkan bahwa sampel sebanyak 100 pasien yang diteliti diketahui bahwa, terdapat 44 orang (44\%) yang memiliki pengetahuan yang tinggi tentang penggunaan antibiotika. Sedangkan sebanyak 39 orang (39\%) responden mempunyai tingkat pengetahuan yang sedang dan $17 \%$ responden (17 orang) mempunyai tingkat pengetahuan kurang [9]. Penggunaan amoksisilin juga terjadi pada seorang anak berusia 18 tahun yang mengalami sakit gigi, kemudian memeriksakan diri di puskesmas yang berada di kabupaten pekalongan dan mendapatkan obat antibiotik amoksisilin, kemudian adapula kasus ketika tangan seseorang remaja terkena oleh benda tajam dan dibawa ke puskesmas di Kabupaten Pekalongan lalu mendapat obat atibiotik amoksisilin.

Penggunaan antibiotik yang tidak tepat seperti tidak tepat dosis dan tidak tepat minum dapat menyebabkan berbagai macam resiko, seperti terjadinya resistensi antibiotik.Kejadian tentang resistensi antibiotik yang disebabkan dari kurangnya pengetahuan masyarakat dan penggunaan antibiotik yang tidak tepat menjadi faktor yang penting, karena ketika pengetahuan tentang sesuatu yang rendah dapat menyebabkan perilaku yang buruk dalam penggunaannya. Hal ini menunjukan bahwa terdapat hubungan antara tingkat pengetahuan dan perilaku masyarakat.Diketahui masih banyak kesalahan dalam pengetahuan tentang antibiotik dan penggunaannya yang tidak tepat.Oleh karena itu, penting adanya penelitian tentang tingkat pengetahuan dan perilaku penggunaan obat antibiotik.

\section{Metode}

Penelitian dilakukan dalam bentuk survei, menggunakan teknik probability sampling dengan metode cluster random sampling danpendekatan cross sectional. Probability sampling merupakan teknik pengambilan yang memberikan peluang yang sama bagi setiap unsur atau anggota populasi untuk dipilih menjadi anggota sampel. Cluster random sampling atau yang biasa disebut dengan teknik sampling 


\section{Prosiding Seminar Nasional Kesehatan Lembaga Penelitian dan Pengabdian Masyarakat Universitas Muhammadiyah Pekajangan Pekalongan

daerah,merupakan teknik sampling yang digunakan untuk menentukan sampel apabila objek yang akan diteliti atau sumber data yang sangat luas. Misalnya penduduk dari suatu negara, provinsi atau kabupaten [10]. Pendekatan cross sectional merupakan suatu metode penelitian yang dilakukan oleh peneliti dengan hanya mengamati objek dalam suatu periode tertentu saja serta tiap objek tersebut hanya diamati satu kali dalam prosesnya [2].

Penelitian ini menggunakan alat berupa kuesioner dengan skala guttman. Pengambilan data pada kuesioner dilakukan secara online melalui link google formuir. Skala guttman yaitu skala pertayaan tertutup berupa jawaban "Ya/Tidak", "Benar/Salah" dengan point penilaian pada kuesioner yang dijawab "benar" adalah "1" dan point penilaian "salah" adalah " 0 ". Analisa yang digunakan untuk melihat hungann antar variabel dengan menggunakan uji statistic Chi-square.

\section{Populasi}

Populasi dalam penelitian ini ialah seluruh siswa-siswi SMA Negeri di Kabupaten Pekalongan. Terdapat 11 sekolah SMA Negeri di Kabupaten Pekalongan yaitu SMA Negeri 1 Bojong, SMA Negeri 1 Kedungwuni, SMA Negeri 1 Sragi, SMA Negeri 1 Wiradesa, SMA Negeri 1 Kesesi, SMA Negeri 1 Talun, SMA Negeri 1 Petungkriyono, SMA Negeri 1 Paninggaran, SMA Negeri 1 Kandngserang, SMA Negeri 1 Doro, SMA Negeri 1 Kajen.

\section{Sampel}

Penetuan sampel sekolah dipilih secara random menggunakan teknik pengocokan dengan kertas sehingga didapatkan hasil yang akan dijadikan sampel penelitian ialah SMA Negeri 1 Bojong, SMA Negeri 1 Kesesi, SMA Negeri 1 Petungkriyono, SMA Negeri 1 Doro. Tiap sekolah diambil responden sebanyak 75 siswa-siswi dengan total responden sebanyak 300 responden

\section{Hasil dan Pembahasan}

Hasil

Tabel 1. Distribusi pengetahuan responden tentang antibiotik

\begin{tabular}{ccccc}
\hline & $\begin{array}{c}\text { SMAN 1 } \\
\text { Bojong }\end{array}$ & $\begin{array}{c}\text { SMAN 1 } \\
\text { Kesesi }\end{array}$ & $\begin{array}{c}\text { SMAN 1 } \\
\text { Petungkriyono }\end{array}$ & SMAN 1 Doro \\
\hline Tinggi & $10(13,3 \%)$ & $16(21,3 \%)$ & $13(17,3 \%)$ & $14(18,7 \%)$ \\
Sedang & $55(73,3 \%)$ & $49(65,3 \%)$ & $48(64,0 \%)$ & $48(64,0 \%)$ \\
Rendah & $10(13,3 \%)$ & $10(13,3 \%)$ & $14(18,7 \%)$ & $13(17,3 \%)$ \\
Mean & 17,64 & 15,63 & 14,07 & 14,24 \\
SD & 1,886 & 2,091 & 2,373 & 2,588 \\
\hline
\end{tabular}


Tabel 2. Distribusi keseluruhan tingkat pengetahuan

\begin{tabular}{cccc}
\hline Kategori & Jumlah & Persentase (\%) & Mean \\
\hline Tinggi & 71 & 23,7 & \\
Sedang & 182 & 60,7 & 2,08 \\
Rendah & 47 & 15,7 & \\
\hline Total & $\mathbf{3 0 0}$ & $\mathbf{1 0 0}$ & \\
\hline
\end{tabular}

Tabel 3. Distribusi perilaku responden tentang antibiotic

\begin{tabular}{ccccc}
\hline & SMAN 1 Bojong & SMAN 1 Kesesi & $\begin{array}{c}\text { SMAN 1 } \\
\text { Petungkriyono }\end{array}$ & SMAN 1 Doro \\
\hline Baik & $34(45,3 \%)$ & $18(24,0 \%)$ & $23(30,7 \%)$ & $35(46,7 \%)$ \\
Cukup & $40(53,3 \%)$ & $54(72,0 \%)$ & $48(64,0 \%)$ & $38(50,7 \%)$ \\
Sedang & $1(1,3 \%)$ & $3(4,0 \%)$ & $4(5,3 \%)$ & $2(2,7 \%)$ \\
Mean & 8,32 & 7,84 & 6,93 & 7,37 \\
SD & 0,756 & 0,916 & 1,004 & 0,983 \\
\hline
\end{tabular}

Tabel 4. Kategori perilaku responden

\begin{tabular}{cccc}
\hline Kategori & Jumlah & Persentase (\%) & Mean \\
\hline Baik & 62 & 20,7 & \\
Cukup & 198 & 66,0 & 2,07 \\
Kurang & 40 & 13,3 & \\
\hline Total & $\mathbf{3 0 0}$ & $\mathbf{1 0 0}$ & \\
\hline
\end{tabular}

Tabel 5. Hasil analisis hubungan tingkat pengetahuan dengan perilaku

\begin{tabular}{ccc}
\hline \multicolumn{1}{c}{ Korelasi } & Konstanta Sig & Nilai sig \\
\hline $\begin{array}{l}\text { Tingkat pengetahuan dengan } \\
\text { perilaku }\end{array}$ & $<0,05$ & 0,000 \\
\hline
\end{tabular}

Pengambilan keputusan menurut Sujarweni (2014):

Jika nilai Sig $<0,05$, maka terdapat hubungan antar dua variable

Jika nilai Sig $>0,05$, maka tidak terdapat hubungan antar dua valiabel [11].

\section{Pembahasan}

Pada penelitian ini dengan judul Hubungan Tingkat Pengetahuan Terhadap Perilaku Penggunaan Obat Antibiotik Pada Siswa SMA Negeri di Kabupaten Pekalongan yang memiliki tujuan untuk mengetahui perbedaan tingkat pengetahuan pada siswasiswi SMA dan mengetahui apakah terdapat hubungan antara tingkat pengetahuan terhadap perilaku penggunaan obat antibiotik pada siswa-siswi SMA Negeri di Kabupatan Pekalongan. Terdapat empat SMA Negeri yang telah terpilih menjadi sampel antara lain SMA Negeri 1 Bojong, SMA Negeri 1 Kesesi, SMA Negeri 1 Petungkriyono dan SMA Negeri 1 Doro dengan total responden per sekolah diambil sebanyak 75 responden. Dari data demografi responden dapat dilihat bahwa obat antibiotik yang dikonsumsi oleh siswa-siswi paling banyak digunakan untuk radang, flu, 


\section{Prosiding Seminar Nasional Kesehatan Lembaga Penelitian dan Pengabdian Masyarakat Universitas Muhammadiyah Pekajangan Pekalongan}

batuk, sakit gigi dan demam, dengan jenis obat antibiotik paling banyak digunakan yaitu antibiotik amoksisillin. Banyak sekali anggapan bahwa obat antibiotik amoksisilin digunakan untuk mengobati penyakit demam dan flu.Hal ini dikarenakan setiap kali berobat baik di sarana kesehatan pemerintah ataupun disarana praktek tenaga kesehatan lainnya sering diresepkan obat antibiotik amoksisilin sehingga timbul asumsi baru dikalangan murid-murid bahwa antibiotik amoksisilin dapat digunakan untuk menyembuhkan penyakit seperti demam dan flu.

Berdasarkan data karakteristik responden pada penelitian ini total keseluruhan responden perempuan sebanyak 222 responden $(74,0 \%)$ sedangkan total keseluruhan responden laki-laki ialah 78 responden $(26,0 \%)$. Hal ini dikarenakan populasi siswa perempuan lebih banyak dibandingkan siswa siswa laki-laki pada SMA Negeri di Kabupaten Pekalongan. Karakteristik umum cara memperoleh obat antibiotik amoksisilin menunjukan sebagian besar obat antibiotik amoksisilin diperoleh di apotek sejumlah 158 responden dengan persentase 52,7\% dilanjutkan di puskesmas sebanyak 51 responden $(17,0 \%)$, di klinik sebanyak 47 responden $(15,7 \%)$, di rumah sakit sebanyak 11 responden (3,7\%), dan di toko obat sebanyak 15 responden (5,0\%). Menurut Zeenot (2013) ditinjau dari kemudahan memperoleh produk obat, banyak orang lebih memilih kenyamanan untuk membeli obat di apotek dibandingkan dengan harus mengantri lebih lama dirumah sakit maupun klinik selain itu obat-obat diapotek lebih dapat dipercaya mutu dan keasliannya sehingga apotek lebih dipilih untuk tempat pembelian obat dari pada toko obat. Karakteristik responden berdasarkan usia pada penelitian ini menunjukan bahwa kelompok responden terbanyak berusia 17 tahun dengan jumlah 180 responden, pada kelompok responden berusia 16 tahun sebanyak 91 responden, pada kelompok usia 18 tahun sebanyak 23 responden, pada kelompok usia 15 tahun sebanyak 2 responden, pada kelompok usia 19 tahun sebanyak 3 responden dan pada kelompok usia 23 tahun sebanyak 1 responden. Hal ini dikarenakan peneliti mengambil tingkat pendidikan responden pada kelas XI saja yang mayoritas siswanya berusia 17 tahun. Karakteristik responden berdasarkan sumber informasi menunjukan bahwa sebagian besar sumber informasi yang diperoleh dari dokter sebanyak 171 responden dengan persentase 57,0\%, dilanjutkan dengan pengalaman pribadi dan keluarga sebanyak 79 responden $(26,3 \%)$, media masa sebanyak 14 responden $(4,7 \%)$ dan teman atau tetangga sebanyak 10 responden (3,3\%). Hal ini disebabkan karena adanya hubungan interpersonal antara pasien dan dokter yang mempengaruhi kepercayaan pasien bahwa dokter bertindak mengatasi masalah medis [4].

Berdasarkan Tabel 1 menunjukkan bahwa SMA Negeri 1 Bojong memiliki nilai rata- rata (mean) paling tinggi dari ke-empat sampel sekolah yaitu 17,64 dilanjutakan dengan SMA Negeri 1 Kesesi yaitu 15,63, SMA Negeri 1 Doro yaitu 14,24 dan SMA N 1 Petungkriyono memiliki nilai rata-rata paling rendah dari ke-empat sampel sekolah 14,07. Perbedaan hasil penelitian ini dapat dipengaruhi oleh beberapa faktor, salah satunya ialah faktor lingkungan.Salah satu upaya untuk meningkatkan pengetahuan siswa-siswi atau masyarakat yang ada ialah dengan memberikan penyuluhan dan konseling, konseling sendiri merupakan kompetensi dari dokter, apoteker dan perawat untuk memberikan informasi serta pembelajaran tentang antibiotik dengan sasaran 


\section{Prosiding Seminar Nasional Kesehatan Lembaga Penelitian dan Pengabdian Masyarakat Universitas Muhammadiyah Pekajangan Pekalongan}

masyarakat luas bukan hanya pribadi saja [6]. Selain itu, pentingnya rasa ingin tahu dari siswa-siswi dan masyarakat petungkriyono terhadap pengetahuan penggunaan obat antibiotik dengan benar, seperti aturan minum, informasi dasar, dan diharapkan agar lebih aktif bertanya kepada petugas farmasi atau membaca artikel obat sehingga dapat menambah pengetahuan yang bermanfaat bagi diri sendiri dan orang lain.

Tabel 2 mennjukkandistribusi keseluruhan tingkat pengetahuan pada siswi SMA Negeri di Kabupaten Pekalongan.Dapat disimpulkan bahwa tingkat pengetahuan tentang obat antibiotik pada siswa SMA Negeri di Kabupaten pekalongan tergolong sedang dengan persentase sebanyak $60,7 \%$. Kategori tinggi sebanyak 71 responden $(23,7 \%)$ dan kategori rendah sebanyak 47 rensponden $(15,7 \%)$. Walaupun mayoritas tingkat pengetahuan pada siswa-siswi SMA Negeri di Kabupaten Pekalongan sedang, tetapi tetap harus ditindak lanjuti dan perlu upaya untuk untuk peningkatan pengetahuan terkait obat antibiotik karena untuk menghindari pemicu terjadinya resistensi.WHO menjelaskan bahwa pengetahuan dapat dipengaruhi oleh pengalamanseseorang, faktor-faktor di luar orang tersebut seperti lingkungan, baik fisikmaupun non fisik dan sosial budaya yang kemudian pengalaman tersebutdiketahui, dipersepsikan, diyakini sehingga menimbulkan motivasi, niat untukbertindak dan akhirnya menjadi perilaku, seperti ketika tertarik akan sesuatu yang nantinya akan dicari entah melalui membaca buku atau membaca artikel yang mana hal tersebut sebagai bentuk perilaku dan tindakan seseorang [5].

Berdasarkan Tabel 3 menunjukan bahwa perilaku penggunaan obat antibiotik amoksisilin dengan rata-rata (mean) tertinggi ialah SMA Negeri Bojong yaitu 8,32. Dilanjutkan dengan SMA Negeri 1 Kesesi yaitu 7,84, SMA Negeri 1 Doro yaitu 7,37 dan rata-rata terendah ialah dari SMA Negeri 1 Petungkriyono yaitu 6,93. Perilaku merupakan suatu perbuatan atau tindakan seseorang dalam melakukan respon terhadap suatu kejadian sehingga dapat dijadikan kebiasaan karena adanya nilai yang diyakini.Perilaku manusia pada hakekatnya adalah tindakan aktivitas diri manusia baik yang diamati langsung maupun tidak dapat diamati oleh interaksi manusia dengan lingkungannya yang terwujud dalam bentuk pegetahuan, sikap dan tindakan [12].

Berdasarkan Tabel 4 yaitu kategori perilaku responden, dapat diketahui bahwa sebagian besar perilaku siswa-siswi SMA khususnya SMA Negeri di Kabupaten Pekalongan memiliki perilaku penggunaan obat antibiotik yang tergolong cukup baik sebanyak 198 responden dengan persentase 66,0\%, dilanjutkan dengan perilaku responden dengan kategori baik sejumlah 62 responden $(20,7 \%)$ dan perilaku responden kategori kurang sejumlah 40 responden (13,3\%). Perilaku penggunaan antibiotik yang benar akan membawa berbagai manfaat seperti mampu meningkatkan efek terapi antibiotik dan menurunkan beban penyakit infeksi seperti terjadinya resistensi. Resistensi merupakan kebalnya bakteri terhadap suatu obat antibiotik sehingga obat antibiotik yang diberikan tidak memiliki efek farmakologis apapun [1]. Resistensi dapat menimbulkan menurunnya kemampuan kerja obat antibiotik serta dapat mengakibatkan peningkatan angka mortalitas, morbiditas, efek samping, lama perawatan, dan peningkatan biaya karena bakteri yang telah resisten akan sulit untuk diobati, oleh karena itu penggunaan obat antibiotik yang benar akan mampu menghindarkan resiko terburuk baik segi klinis maupun ekonomi [3]. 


\section{Prosiding Seminar Nasional Kesehatan Lembaga Penelitian dan Pengabdian Masyarakat Universitas Muhammadiyah Pekajangan Pekalongan}

Pada Tabel 5 menunjukan bahwa hasil analisis hubungan tingkat pengetahuan dengan perilaku responden menunjukan adanya hubungan antar variabel pengetahuan dengan variabel perilaku.Data hubungan tingkat pengetahuan dengan perilaku diuji dengan uji korelasi Chi-square.Uji Chi-square digunakan karena data yang diperoleh tidak normal yaitu 0,001 sesuai dengan syarat pengambilan keputusan uji normalitas menurut Sujarweni (2014) jika Sig< 0,05 maka data berdistribusi tidak normal, sebaliknya jika Sig > 0,05 maka data berdistribusi normal. sehingga digunakan analisis non parametrik untuk mengetahui hubungan antara pengetahuan terhadap perilaku penggunaan obat antibiotik. Dimana nilai sig menunjukan angka 0,000 yang artinya nilai tersebut kurang dari nilai konstanta 0,05. Jika dilihat dari pengambilan keputusan maka dapat dinyatakan kedua variabel tersebut berhubungan.Adanya hubungan antara pengetahuan dengan perilaku dikuatkan dengan teori Lawrence green bahwa perilaku dapat dipengaruhi oleh faktor predisposisi yang mencakup pengetahuan, sikap, keyakinan dan nilai. Pengetahuan umumnya datang dari pengalaman, baik itu pengalaman pribadi maupun pengalaman orang lain. Selain itu pengetahuan juga datang dari pendidikan yang mencakup masalah perilaku individu maupun kelompok (Triwibowo, 2017). Akan tetapi jika dilihat lagi dari Tabel 5 bahwa hasil korelasi antara pengetahuan dengan perilaku yaitu 0,000 yang artinya kedua variabel ini memiliki hubungan yang lemah sesuai dengan teori Riyanto (2017) menjelaskan bahwa korelasi antara 0,00-0,25 memiliki tingkat hubungan yang lemah. Hal ini dapat disebabkan karena perilaku yang dimiliki oleh responden bukan hanya dipengaruhi oleh pengetahuan.

\section{Kesimpulan}

Berdasarkan hasil penelitian yang telah dilakukan terhadap 300 responden di SMA Negeri Kabupaten Pekalongan dapat disimpulkan bahwa kategori tingkat pengetahuan responden terhadap antibiotik pada siswa SMA Negeri di Kabupaten Pekalongan adalah sedang dengan persentase sebanyak 60,7\%, kategori perilaku responden terhadap penggunaan obat antibiotik pada siswa SMA Negeri di Kabupaten pekalongan adalah cukup baik dengan persentase sebanyak $66,0 \%$ dan terdapat hubungan antara tingkat pengetahuan dengan perilaku penggunaan obat antibiotik dengan nilai signifikansi 0,000 .

\section{Referensi.}

[1] Dermawan, D,"Farmakologi untuk keperawatan,"Yogyakarta: Gosyen Publishing, 2015.

[2] Hasmi,"Buku Saku Statistik Kesehatan, "Jakarta : RGC Ed, 2012.

[3] Kurniawati, L. H.,"Hubungan Pengetahuan Masyarakat Terhadap Perilaku Penggunaan Antibiotik,"Skripsi, Universitas Islam Negeri Maulana Malik Ibrahim Malang, Fakultas Kedokteran dan Ilmu Kesehatan, Malang, 2019.

[4] Pandean, F., \& dkk. "Profil Pengetahuan Masyarakat Kota Manado Mengenai Antibiotika Amoksisilin,"Jurnal IImiah Farmasi, 2(2). 2013. 


\section{Prosiding Seminar Nasional Kesehatan Lembaga Penelitian dan Pengabdian Masyarakat Universitas Muhammadiyah Pekajangan Pekalongan}

[5] Pertiwi, R. N.,"Tingkat Pengetahuan Tentang Antibiotik Pada Mahasiswa Universitas Muslim Nusantara," Skripsi, Universitas Sumatera Utara, Fakultas Farmasi, Medan. 2018.

[6] Rahmawati,"Pengetahuan dan Sikap Masyarakat Terhadap Antibiotik di Puskesmas Kota Jantho Kecamatan Kota Jantho Kabupaten Aceh Besar,"Skripsi, Universitas Sumatera Utara, Fakultas Farmasi, Medan. 2017.

[7] Rao, R. S., \& Nanda, S. R. "Amoxicillin: A Broad Spectrum Antibiotic," International Journal of Pharmacy and Pharmaceutical Science, 3(3), 30-37.2011.

[8] Riyanto, A. "Statistik Inferensial Untuk Analisis Data Kesehatan," Yogyakarta: Nuha Medika, 2017.

[9] Septiana, R., \& Khabib, M. I.,"Perbedaan Tingkat Pengetahuan Siswa SMK Kesehatan dan SMK non Kesehatan terhadap Penggunaan Antibiotik,"Jurnal Farmasetis, 2(8), 89-94.2019.

[10] Sugiyono,"Metodologi Penelitian Kuantitatif, Kualitatif dan R\&D Cetakan Ke-II," Bandung: Alfabeta.2011.

[11] Sujarweni, W. V., "Penelitian Keperawatan dengan SPSS, Yogyakarta: Graha IImu, 2014.

[12] Triwibowo, C., \& Pusphandani, M. E. "Pengantar dasar ilmu kesehatan masyarakat cetakan II,"Yogyakarta: Nuha Medika, 2017.

[13] Zeenot, S., 'Pengelolaan \& Penggunaan Obat Wajib Apotek,"DMEDIKA, 2013. 